\title{
THE PLANNING PROCESS DURING MILITARY DECISION
}

\author{
Venelin Terziev $^{1}$, Redon Koleci ${ }^{2}$, Denis Solovev ${ }^{3}$ \\ ${ }^{1}$ Full Member of the Russian Academy of Natural History, Professor, Eng,
} D.Sc. (National Security), D.Sc. (Economics), D.Sc. (Social Activities), Ph.D., Russian Academy of Natural History, Moscow, Russia, Vasil Levski National Military University, Veliko Tarnovo, Bulgaria University of Rousse, Rousse, Bulgaria, terziev@skmat.com

${ }^{2}$ Ph.D. Student, National Military University, Veliko Tarnovo, Bulgaria, redon_koleci@hotmail.com

${ }^{3}$ Associate Professor, Ph.D., Far Eastern Federal University (FEFU), Vladivostok, Russian

Federation, solovev.db@dvfu.ru

\begin{abstract}
The planning process during military decision-making helps executives apply thoroughly, clearly, with sound, logical judgment, with knowledge and understanding of the situation, situation development and problem solving during a rich decision making. Through this method commands, staffs and others find it easier to think critically, creatively as they plan.

The purpose of the planning process during military decision-making is to work out a good plan that emerges from the decision-making process which, although not implemented as planned, facilitates rapid and efficient action or modification when unforeseen events occur.
\end{abstract}

Keywords: planning process, military decision making, emergencies, operational plans.

\section{INTRODUCTION}

The planning process is used by management in defining goals, strategies, policies and plans using assistive forecasting and forecasting techniques of the organization's external and internal environment. Through planning, managers try to predict the future, anticipate and prepare for the occasional and eventual shocks that come from changes in the environment. The planning cycle foresees development trends, and the continuation of the acquisition of certain actions and concludes with the follow-up and evaluation of the effects of the actions taken. During military decision-making, the planning process helps coordinate the activities of the commander, staff, subordinate staff and other partners (Koleci, 2008).

The planning process during military decision-making helps executives apply thoroughly, clearly, with sound, logical judgment, with knowledge and understanding of the situation, situation development and problem solving during a rich decision making. Through this method commands, staffs and others find it easier to think critically, creatively as they plan.

The military decision-making process must be flexible, understandable, continuous, focused on future operations. In this way they will be able to identify potential risks and make a risk assessment, thereby identifying and managing the risk that will come from operational and decision-making factors.

The purpose of the planning process during military decision-making is to work out a good plan that emerges 
from the decision-making process which, although not implemented as planned, facilitates rapid and efficient action or modification when unforeseen events occur. . During the execution of the plan that was created in the planning process they are reformulated and updated according to the current situation and the new mission and may be required by the commander to resume the decision making process (Robbins, DeCenzo, 2011).

The planning process during military decision-making helps to fully understand the situation and vision for the battlefield, helping the commander to formulate and sketch his initial intent. Presenting the mission analysis briefing informs the commander of the results of the staff and situational analysis. As the most important participant in the military decision-making process, the commander uses his experience, knowledge, and judgment in directing staff planning efforts. The military decision-making process through several forms of meetings and briefings between the commander and the staff discusses, displays and approves or not its plan and progress (Horvat, Kovacic, 2008a).

The objectives that will be realized through scientific research are:

- Studying the planning process during military decision making;

- Analyzing the development of the planning process during military decision-making and the functions of the decision-making process;

- Presentation of organizational structure and models of military decision-making;

- Define emergency operational plans in the planning process in military decision-making;

- Reaching recommendations and conclusions about the planning process during military decision making.

The military decision-making process provides collaborative planning as senior staffs seek inclusive thinking and continually share and exchange information with subordinates and neighbors, support units, and other partners about expected operations, through planning meetings, warnings, and other means.

Commanders encourage active co-operation between all structures involved in the expected operation to have a common understanding of the situation, participate in designing action options and decision-making, and resolve potential conflicts before the operational plan or order is distributed.

During planning, evaluation focuses on developing an understanding of the current situation as well as determining what and how to evaluate progress using performance measurement and effectiveness measurement measures.

\section{EXECUTION AND PLANNING DURING MILITARY DECISION MAKING}

The military decision-making process is a method of planning used by ground forces. The military decisionmaking process is a cyclical iterative planning methodology to understand the situation and mission, to build the variant of action, and to design the operational plan or order. The military decision-making process helps executives use clarity, sound judgment, logic and professional knowledge to understand situations, design problem-solving options, and arrive at a decision. This process helps commanders and staffs think creatively and critically when planning (2015; 2014-a; 2009-b).

The decision-making process also precedes preparations. While time is a factor in all operations, commanders and staff conduct time analysis from the outset of the planning process. This analysis helps them determine what actions are required and when these actions should be initiated to ensure that forces are deployed in combat order before the operational order is implemented.

This may require the commander to order subordinates to initiate the necessary moves, make changes to the task organization, initiate information gathering activities, and perform other preparatory actions before completing the plan. The commander gives these orders through a series of warning orders as the commander and staff develop the military decision-making process.

The decision-making process can be as detailed as the time available, resources, experience and situation allow. Following all the steps and steps of the process is a long, detailed and time consuming procedure. Commanders fully develop the decision-making process, following all steps of this process, when they have sufficient time and staff to analyze two or more variants of action and build a fully operational plan or order of operations. Synchronized. Typically this happens when planning for a completely new mission.

Commanders can modify the steps of the decision-making process to adapt to limited time conditions and to design an appropriate plan. In limited time conditions, commanders evaluate the situation, update the commander's view of the operation, and direct the staff to carry out the decision-making process in the 
interest of decision-making. In situations where time is extremely limited, commanders rely more in intuitive decision making techniques such as fast decision making and process synchronization.

The commander and headquarters analyze the data and subordinates in the current task organization, command and support relationships, and the status (current opportunities and constraints) of all units or units. This analysis also includes the capacities of civilian and military structures (unified, special and multinational operations) operating in the unit's area of operation. They take into account the relationship between specified, implicit and main tasks as well as between them and the assets available. From this analysis, the $\mathrm{HQ}$ determines whether it has the assets needed to complete all these tasks. If there are deficiencies, they identify the additional resources needed to successfully accomplish the mission and send it to superior staff.

The headquarters also identifies any deviations from the normal organization of duty and informs the commander in order to be kept in mind for planning instructions. A more detailed analysis of the available assets is made when designing the action variant.

Plans and orders are based on facts and assumptions. Commanders and staffs gather facts (or data) and formulate assumptions as they begin to build their plan. Fact is called a real and real data or thought to be such at that time. Facts about mission and operation factors form the basis for understanding the situation, for planning continuity, and for evaluating progress in the preparation and implementation of the operation.

Assumption is a conjecture about the current situation or events foreseen to happen in the future, accepted as true in the absence of reliable but necessary information in the planning process to develop complete situational assessments and decision making regarding with the action variant. In the absence of any facts, the commander and staff take into account the assumptions of the staff and superior command. After that they formulate their assumptions necessary for the continuation of planning. When using assumptions when planning, it is a permanent requirement for the $\mathrm{HQ}$ to work on their replacement with facts. The commander and staff should list and review the key assumptions underlying the judgment during the decision-making process. Reviewing assumptions is valuable at all times before making an assessment or judgment as well as in making a decision.

The main techniques used to save time are: increasing commander participation in the process, limiting the number of variants to be drafted, maximizing parallel planning, enhancing collaborative planning, using liaison officers (representatives).

Involvement of commanders in the planning headquarters, the greater their involvement and involvement in planning, the faster the staff can plan. Commanders who participate in the planning process when time is limited, then they can make decisions without waiting for detailed staff briefings.

Limiting the number of variants of action to design and play in the combat game can save time. If the time is very limited, the commander can order only one variant of action. Variant which must be acceptable that meets the mission requirements within the time available. This technique saves most of the time. The fastest way to devise a plan is for the commander to order the design of only one variant of action, together with its ramifications, against the most likely variant of enemy action or the worst humanitarian or civilian situation.

This technique should only be used when time is very limited, in which case this choice of action option is often intuitive based on the commander's experience and judgment. The commander may also include subordinate commanders, if possible, by participating in person or by video conferencing via secure digital networks. This team is rapidly developing a flexible action variant that is believed to complement the mission. The commander develops the combat game of this variant in his mind and then gives it to the staff to complete and upgrade.

Parallel planning is a norm that is important to maximize under limited time. The importance of warning orders increases as the time available decreases. An oral warning order, followed by a written order later saves more time than a written order an hour later. When the decision-making process is shortened, the HQ uses the same format as the warning order used in the normal military decision-making procedure. In addition to the warning order, units and wards should share with their subordinates the information they have as soon as possible. The headquarters uses every opportunity to carry out parallel planning with superior headquarters and sharing information with subordinates.

Real-time planning with superior staff and subordinates improves the overall planning effort of the relevant structure. The modern communication system, including the electronic communication of picture of the situation of the operation situation, allows cooperation with subordinates regardless of distance, enhances the exchange of information and improves the commander's image of the operation. Furthermore, taking 
advantage of subordinates' participation together with their data on the situation in their area of operation often results in faster and better design of the action variant.

Liaison officers assigned to superior commands and partner staffs, participating in unified actions, make it possible for the commander to have representatives during the planning process at the superior headquarters. As commander's representatives, liaison officers should:

- Understand what their commander thinks and be able to interpret the commander's oral and written instructions;

- Broadcast their commander's purpose, planning instructions, mission and idea of operation;

- Represent the position and attitude of their commander;

- To know the mission of the unit or unit they represent; tactics, techniques, procedures; organization; communication facilities and equipment;

- Monitor established command channels and staff functions;

- Be trained in their functional responsibilities;

- Be and act tactfully;

- Have the appropriate level of communication language.

The military decision-making process is one of three military planning methodologies. The military decisionmaking process is an iterative planning methodology to understand the situation and mission, to develop a course of action, to create a plan or order.

The military decision-making process helps leaders apply precision, clarity, sound judgment, logic and professional knowledge to understand the situation, develop problem-solving options, and make decisions. This process helps commanders, staffs, and others think critically and creatively as they plan (2009-b).

A model is a process used to create a simple representation of the problem. A model can be defined as the representation of a part of the process that includes only those elements which affect the set objective. A model is not a perfect copy of the process, but it contains enough details of it. There are many ways to classify models, but the most useful way is to split the models into:

- Abstract patterns;

- Exact patterns.

Abstract patterns are unorganized, well-represented representations of reality. They have no physical or symbolic configuration. Exact models have some physical characteristics that resemble the reality we are studying. But between the two extremes above there are symbol models such as theories, mathematical applications, assertions, etc. (Nichev, 2009c; Terziev, Bogdanova, Kanev, Georgiev, 2019; Petrov, Georgiev, 2019a; Georgiev, 2019b).

\section{CONCLUSION}

The military decision-making process is known as cyclic planning methodology understanding the situation and mission, builds the variant of action, and drafts the operational plan or order. Through the military decision-making process leaders use clarity, sound judgment, logic and professional knowledge to assess the situation and devise options for problem solving (Terziev, Bogdanova, Kanev, Georgiev, 2019c-d).

The difference between the planning process in the organization of the business enterprise and the planning process in the organization of the military establishment differs in problem solving. In the organization of a business enterprise, although it may be very similar to the steps to be followed, it is an easier method to achieve the implementation of the decision than the planning process in the organization of the military establishment (Georgiev, 2017; Glushkov, Simeonov, Georgiev, 2018).

The type of environment within which the organization operates has a significant impact on the decisionmaking process and the degree of uncertainty of these decisions. Moving from a simple to a complex environment and from a static to dynamic environment increases the degree of environmental uncertainty (Bogdanov, 2016; Bogdanov, 2019e-f). 


\section{REFERENCE LIST}

Koleci, Baki (2008). Management (Fundamentals of Management), Pristina, 2008.

Robbins, S., DeCenzo, D. (2011). Fundamentals of Management - Basic Concepts and Applications, Sixth Edition, UET PRESS 2011.

Horvat, D., Kovacic, M. (2008a). Management in the Small Economy, Croatia 2008.

Military Decisionmaking Process (2015). HANDBOOK, No 15-06, Aproved for Public Release Distribution Unlimited; March 2015.

FM 6-0 Commander and staff organization and operations (2014). Headquarters, Department of the Army; Washington, May 2014.

Staff Officer's, Quick Reference Guide (2014a). Version 3, U.S. Unclassified REL NATO, ISAF, FVEY, September 2014.

A02.08 Crisis Management / Emergency - Learning Handbook (2009). NTT TRADOC, January 2009, NATO / KFOR UNCLASSIFIED.

A02.07 Project Management (2009a). Textbook, NTT TRADOC, January 2009, NATO / KFOR UNCLASSIFIED.

A02.09 Staff Functions and Responsibilities (2009b). Lesson Manual, NTT TRADOC, January 2009, NATO / KFOR UNCLASSIFIED.

Nichev, N. (2009). Historical analysis of the involvement of joint armed forces in humanitarian operations. // 15th International Conference on Knowledge-Based Organization, 26-28 Nov 2009: Military Sciences. Security and Defense, Conference Proceedings 1, Volume: 1, Pages: 104-108, Sibiu, Romania, 2009.

Terziev, V., Bogdanova, M., Kanev, D., Georgiev, M. (2019). Uses of the strategic card in the republic of Bulgaria's land forces. // Proceedings of ADVED 2019 - 5th International Conference on Advances in Education and Social Sciences, 21-23 October 2019, International Organization Center of Academic Research, Istanbul, Turkey, 2019, pp. 519-525, ISBN: 978-605-82433-7-8.

Petrov, N., Georgiev, M. (2019a). Assessing of the military professional competencies. // Proceedings of SOCIOINT 2019- 6th International Conference on Education, Social Sciences and Humanities 24-26 June 2019- Istanbul, Turkey, International Organization Center of Academic Research, Istanbul, Turkey, 2019, pp. 462-472, ISBN: 978-605-82433-6-1.

Georgiev, M. (2019b). Improvement of the forming of the military professional qualities during the educational process. // 21 st International scientific conference: The teacher of the future, Budva, Montenegro, (07-09.06.2019), Institute of knowledge management - Skopje, Macedonia, 31, 2019, 6, pp. 1945-1950, ISSN 1857-923X (for e-version), ISSN 2545 - 4439 (for printed version).

Terziev, V., Bogdanova, M., Kanev, D., Georgiev, M. (2019c). The cadets and the reasons for their drop-out of the National Military University. // Proceedings of ADVED 2019 - 5th International Conference on Advances in Education and Social Sciences, 21-23 October 2019, International Organization Center of Academic Research, Istanbul, Turkey, 2019, pp. 398-406, ISBN: 978-605-82433-7-8.

Terziev, V., Bogdanova, M., Kanev, D., Georgiev, M. (2019d). The cadets from the military schools as subjects of educational activity. // Proceedings of ADVED 2019 - 5th International Conference on Advances in Education and Social Sciences, 21-23 October 2019, International Organization Center of Academic Research, Istanbul, Turkey, 2019, pp. 407-418, ISBN: 978-605-82433-7-8.

Georgiev, Marin. (2017). The Role of the Balanced Scorecard as a tool of strategic management and control. // Journal of innovations and sustainability, Plovdiv, Bulgaria, 3, 2017, N 2, pp. 31-63, ISSN 2367-8127 (CD-ROM), ISSN 2367-8151 (on-line).

Glushkov, P., Simeonov, S., Georgiev, M. (2018). Method of determination of the diurnal energy consumption of the cadets from the Vasil Levski National Military university. // ADVED 2018- 4th International Conference on Advances in Education and Social Sciences Abstracts \& Proceedings, 1517 October 2018- Istanbul, Turkey, International Organization Center of Academic Research, www.ocerints.org, Istanbul, Turkey, 2018, pp. 88-92, ISBN: 978-605-82433-4-7.

Bogdanov, Plamen. (2016). Air power - Today and tomorrow. // Tenth international scientific conference: The power of knowledge 7-9.10.2016, Agia Triada, Greece, IKM - Skopje, 14, 2016, N 1, pp. 331-336, ISSN 1857-92. 
Bogdanov, Plamen. (2019e). Wath Happened That Lead To The War In Kosovo. Institute of Knowledge Management, Scientific Papers, Social Sciences, International Journal Knowledge, Vol.30. 6., Skopie, 2019 - ISSN 2545 - 4439, pp. 1511 - 1516.

Bogdanov, Plamen. (2019f). Perspectives and development of the the Bulgarian military - educational system. // Security of Central and Eastern Europe Countries 1st International Scientific Conference of Military Academies/Universities, WROCLAW, 20-22.03.2019, organized by General Tadeusz Kosciuszko Military University of Land Forces, Scientific Journal of the Military University of Land Forces, volume 50, no. 1 (187), 2019, pp. 73-89, ISSN 2544-7122. 